4. Manno S, Takakuwa Y, Nagao K, Mohandas N. Modulation of erythrocyte membrane mechanical function by beta-spectrin phosphorylation and dephosphorylation. J Biol Chem 1995;270:5659-5665.

5. Ideguchi H, Yamada $Y$, Kondo S, Tamura K, Makino S, Hamasaki N. Abnormal erythrocyte band 4.1 protein in myelodysplastic syndrome with elliptocytosis. Br J Haematol 1993;85:387-392.

6. Majumder D, Banerjee D, Chandra S, Banerjee $S$, Chakrabarti A. Red cell morphology in leukemia, hypoplastic anemia and myelodysplastic syndrome. Pathophysiology 2006;13:217-225.

\title{
Intradiploic Hematoma in a Hemophilic Patient: Hemophilic Pseudotumor of Calvarium
}

\author{
Hemofilik Bir Hastada Intradiploik Hematom: Kraniyumun Hemofilik Psödotümörü
}

\author{
Hakan Hanımoğlu¹, Zafer Başlar² \\ 1 Istanbul Bilim University Faculty of Medicine, Department of Neurosurgery, Istanbul, Turkey \\ 2 Istanbul University Cerrahpaşa Faculty of Medicine, Department of Internal Medicine, Division of Hematology, Istanbul, Turkey
}

To the Editor,

Pseudotumors are results of repeated hemorrhage into soft tissues, the subperiosteum, or a site of bone fracture with inadequate resorption of the extravasated blood. We describe a patient with a huge hemophilic pseudotumor of calvarium, which occurs very rarely.

A 14-year-old boy with mild hemophilia A (FVIII coagulant activity: 5.8\%) without inhibitor presented with epileptic seizure 7 years ago. The patient was known to be hemophiliac from birth after a birth injury and brain damage had occurred. He was mentally retarded and had habitual head-hitting behavior. His family noticed progressively enlarging painless scalp swelling on his head.

There was obvious asymmetry of the head and face (Figure 1, A-3). His neurological examination was normal and radiological investigations did not reveal any other pathology. A computed tomography (CT) scan showed a large lesion with a mass effect over the underlying brain (Figure 1, A-1 and A-2).

Surgery was carried out with coagulation factor replacement (FVIII). During surgery a skin flap was done and the thinned outer table was incised (Figure 1, B-1). Mud-like material and a liquefied clot were evacuated (Figure 1, B-2). The thin and elastic inner wall was not removed to avoid postoperative complications (Figure 1, B-3).

Following surgery, antiepileptic medication was continued and short-term prophylaxis (30 IU/kg, three times a week) was applied for 8 weeks. At the 7-year follow-up of the patient, he was free of seizures and a CT scan of the patient showed that acceptable calvarial remodeling had occurred (Figure 1, C-1 and C-2).

Proximal pseudotumors may destroy the soft tissues, erode the bone, and cause serious vascular and/or nerve damage [1].

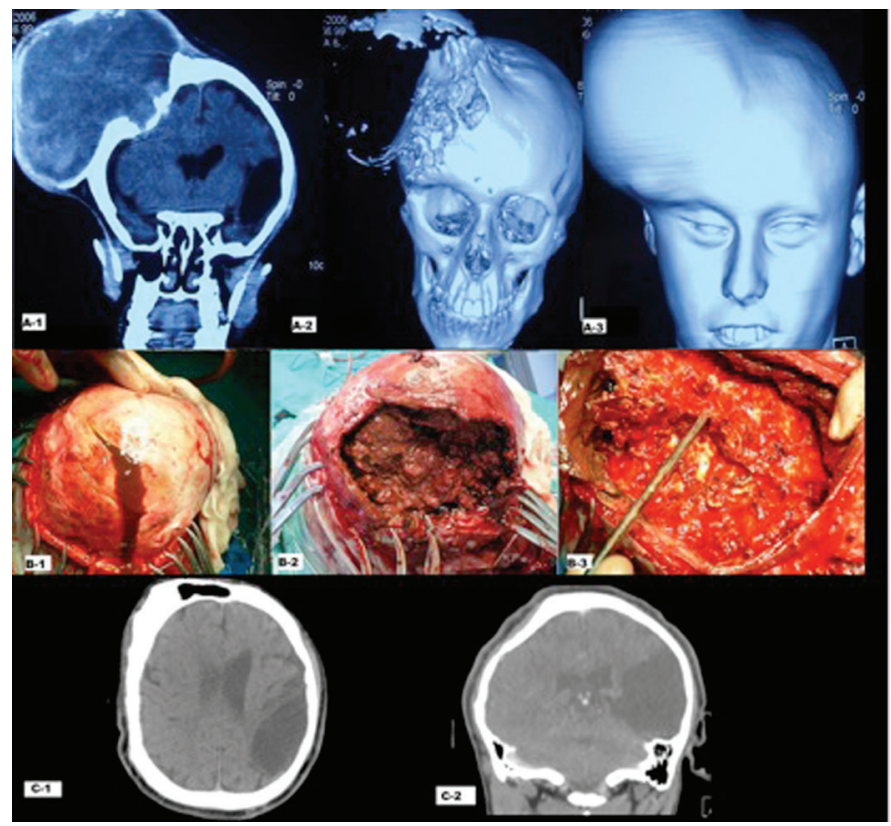

Figure 1. A-1, A-2, A-3: Multidetector computed tomography scan with reconstruction shows large lytic intradiploic lesion with expansion and scalloping of the bony margins; please note that the inner and outer tables are separated and destructed. B-1, B-2, B-3: Intraoperative images; evacuated lesion was mudlike, inner table was protected. C1, C2: Sagittal and coronal computed tomography images after 7 years; good and acceptable remodeling of the calvarium is seen. 
Reduction of the pseudotumor and chronic joint disease is achieved by prophylactic treatment in severe hemophilia.

Calvarial localization of a pseudotumor is unusual [2]. Inflammation due to hematoma causes immune reaction and affects nearby tissues. The skull tables provide natural protection from soft tissues being eroded [3]. All intradiploic lesions should be suspected to be hematomas unless proven otherwise in patients with coagulopathies [2].

Total surgical removal of the hematoma is the treatment of choice. Some authors recommend cosmetic cranioplasty within the same surgical procedure [4]. However, most of them prefer to preserve the intact inner table [5]. According to us, the elastic inner table must be preserved to avoid postoperative complications. Acceptable bone remodeling was seen in the seventh year of follow-up in control CT images. However, a noncompressible inner table must be excised.

In summary, intradiploic hematoma must be expected when an intradiploic lesion is seen with hemophilia. The main part of the surgery is the preservation of the inner table of the cranium in hemophilic patients. Bone remodeling gives good results with time.
Keywords: Hemophilia A, Intradiploic hematoma, Coagulopathy, Intraosseous

Anahtar Sözcükler: Hemofili A, İntradiploik hematom, Koagülopati, İntraosseoz

Conflict of Interest: The authors of this paper have no conflicts of interest, including specific financial interests, relationships, and/ or affiliations relevant to the subject matter or materials included.

\section{References}

1. Rodriguez-Merchan EC. Musculo-skeletal manifestations of haemophilia. Blood Rev 2016;30:401-409.

2. Mobbs RJ, Gollapudi PR, Fuller JW, Dahlstrom JE, Chandran NK. Intradiploic hematoma after skull fracture: case report and literature review. Surg Neurol 2000;54:87-91.

3. Reeves A, Brown M. Intraosseous hematoma in a newborn with factor VIII deficiency. AJNR Am Neuroradiol 2000;21:308-309.

4. Tokmak M, Ozek E, Iplikçioğlu C. Chronic intradiploic hematomas of the skull without coagulopathy: report of two cases. Neurocirugia (Astur) 2015;26:302-306.

5. Dange N, Mahore A, Avinash KM, Joshi V, Kawale J, Goel A. Chronic intradiploic hematoma in patients with coagulopathy. J Clin Neurosci 2010;17:1047-1049.

\title{
The Second and Third Hemoglobin Kansas Cases in the Turkish Population
}

\section{Türk Popülasyonundaki İkinci ve Üçüncü Hemoglobin Kansas Olguları}

\author{
Zeynep Kayra Tanrıverdi1, Arzu Akyay², Aşkın Şen³, Çağatay Taşkapan4, Ünsal Özgen² \\ 1Inönü University Faculty of Medicine, Department of Pediatrics, Malatya, Turkey \\ 2 Inönü University Faculty of Medicine, Department of Pediatric Hematology and Oncology, Malatya, Turkey \\ ${ }^{3}$ FIrat University Faculty of Medicine, Department of Medical Genetics, Elazığ, Turkey \\ 4inönü University Faculty of Medicine, Department of Biochemistry, Malatya, Turkey
}

To the Editor,

We read with great interest the article by Keser et al. [1] regarding the first observation of hemoglobin Kansas in Turkey. The authors described a patient from Malatya as the first case of hemoglobin Kansas in the Turkish population. After the publication of this paper, we had two other hemoglobin Kansas cases from the Malatya region.

Case 1: A 16-year-old female patient was admitted with the complaint of cyanosis of her lips and nails since birth, but she had no problems in her daily life. In her family history, there were other relatives who had the same complaints (Figure 1a). Physical examination of our patient indicated slight cyanosis of her lips, nail beds, and skin (Figure 2). Other system examinations were normal. Transcutaneous oxygen saturation was detected as 50\%. Her complete blood count, electrocardiogram, echocardiogram, methemoglobin level, and peripheral blood smear were normal. In blood gas values, $\mathrm{pH}$ was 7.39, $\mathrm{PCO}_{2}$ was $41.1 \mathrm{mmHg}, \mathrm{PO}_{2}$ was $66.3 \mathrm{mmHg}$, and the P50 value was 66.94 (normal value: 24- 